\title{
Ameliorative Potential of Rengyolone Against CCI-induced Neuropathic Pain in Rats
}

\author{
Gil-Hyun Lee ${ }^{1, *}$ and Kyung-Yae Hyun ${ }^{2, ;, *}$ \\ ${ }^{1}$ Department of Clinical Laboratory Science, Dong-Seo University, Busan 47011, Korea \\ ${ }^{2}$ Department of Clinical Laboratory Science, Dong-Eui University, Busan 47340, Korea
}

\begin{abstract}
The sciatic nerve is the largest nerve among the peripheral nerves, and the damage to the sciatic nerve is caused by mechanical and physical pressure. This is an important disease that consumes a lot of time and money in the treatment process. Among them, research on relieving nerve pain caused by damage to the peripheral sciatic nerve has been made efforts to prevent and treat this disease through various methods such as drugs, natural products, electrical stimulation, exercise therapy, and massage. Existing treatments are not very effective in neurological pain, and countermeasures are needed. Forsythia Fructus, used in this study, has been used as a therapeutic agent for infectious diseases and a pain reliever for cancer from the past, and in past studies, it has been known to properly control the inflammatory response. In this study, rengyolone, a physiologically active substance of Forsythiae Fructus, was administered to rats that caused chronic left nerve pain to verify the pain relief effect. As a result of the experiment, it was found that mechanical pain and cold stimulation pain were significantly reduced in the rengyolone-treated group compared to the non-administered group. In addition, it was found that nerve growth factor (NGF) mRNA expression was significantly reduced and Cyclin-dependent kinase $2(\mathrm{Cdc} 2)$ expression was increased in the rengyolone administration group. This increase in NGF expression is thought to be related to rengyolone's anti-inflammatory regulatory mechanism. It is expected that the reduced NGF was directly involved in pain relief.
\end{abstract}

Key Words: Forsythiae Fructus, Rengyolone, NGF, Cdc2, Animal behavior

\section{서 론}

말초신경계의 손상이나 질환은 신경의 병변이나 척수 와 뇌신경핵의 병변으로 인해 발생할 수 있는데, 그 중 60 70\%는 말초신경 자체의 병변이며 현대 사회에서는 교통사고와 같은 외상성 손상이 증가하고 있다(Milligan et al., 2005). 그 중 좌골신경은 말초신경 가운데 가장 큰 신경으로, 좌골신경 손상은 기계적, 물리적인 압박이 가해 져 발생하게 되며 신경의 분포를 따라서 동통을 일으키
고 심하면 근력저하, 근위축이 발생하게 되는 것으로 유 병률과 병의 이환범위가 넓으며 치료과정에서 시간과 비 용이 많이 소모되는 중요한 질병이다(Schäfers and Sommer, 2007). 이 중 좌골 말초신경 손상에 의한 신경통증 완화 에 대한 연구는 약물, 천연물, 전기자극, 운동요법, 마사 지 등 다양한 방법을 통하여 이 질환을 예방하고 치료하 는 노력이 이루어지고 있다(Attal et al., 2006).

통증은 구심성 일차섬유(C-fiber)와 유수섬유(A deltafiber)의 활성화에 의해 유발된다고 알려져 있으며(Staud et al., 2007), C-유해수용기는 자극이 없으면 활동하지 않으며,

Received: September 13, 2020 / Revised: October 21, 2020 / Accepted: November 24, 2020

* Professor.

$\dagger$ Corresponding author: Kyung-Yae Hyun. Department of Clinical Laboratory Science, Dong-Eui University, Busan 47340, Korea.

Tel: +82-51-890-2683, Fax:+82-0505-182-6877, e-mail: kyhyun@deu.ac.kr

(C) The Korean Society for Biomedical Laboratory Sciences. All rights reserved.

(c) This is an Open Access article distributed under the terms of the Creative Commons Attribution Non-Commercial License (http://creativecommons.org/licenses/by-nc/3.0/) which permits unrestricted non-commercial use, distribution, and reproduction in any medium, provided the original work is properly cited. 
유해한 자극에 잘 반응한다고 하며(Djouhri et al., 2006), 비 정상적으로 활성화된 C-fiber가 신경병성 통증(neuropathic pain)에 기여한다고 알려져 있다(Ahlgren et al., 1996; Staud et al., 2008). 신경이 압박이나 절단에 의해서 손상되면 손 상된 축삭의 말단에서는 재생하는 현상이 나타나며, 이러 한 신경은 온도, 물리적, 화학적 자극에 대한 민감성이 증 가한다고 알려져 있다(Hofmann etal., 2003).

통증의 기전을 이해하고, 효과적인 치료약물이나 치료 법을 개발하는 동물통증모델은 필수적인 요소이다. 지난 수십년간 연구자들은 수술적인 방법, 약물 투여 방법, 혹 은 이물을 삽입하는 방법 등 다양한 방법을 이용하여 각 상황에 맞는 동물통증모델을 설계하였으며(Bennett and Medicine, 1993), 이 중 신경압박 방법을 이용하여 유발한 말초신경병성 동통모델이 개발되어 오랫동안 이용되어 왔 다. Bennett의 만성적인 압박손상모델(chronic injury model; $\mathrm{CCI}$ )은 좌골신경(sciatic nerve)의 둘레를 느슨하게 묶어 신 경에 손상을 주며 이 방법은 사람에게서 발생하는 신경 병성 동통 증후군이 동물에게 유사하게 발병하는 것으로 알려져 있다(Bennett and Xie, 1988).

신경병성 통증모델이 유발된 동물은 자발통, 통각 과민, 이질통 등을 특징으로 하는 만성 통증을 격으며, 기계 적 자극과 열 자극에 민감도가 증가한다고 알려져 있다 (Raghavendra et al., 2003). 임상에서는 신경병리성 통증을 조절하기 위하여 교감신경계의 처지를 통한 통증 완화, 아편계 약물 투여, lidocaine, capsaicin, 항우울제, 항경련제 등의 약물 투여, 항산화제를 이용한 reactive oxygen species (ROS) 제거, 말초의 경피적 신경자극, 마지막으로 내인성 통증 억제계의 활성화 등 다양한 방법을 이용하고 있다 (Ziegler et al., 1995; Low et al., 1997; Ziegler and reviews, 2008). 통상 동물모델에서 물질 투여 후 통각 과민의 감 소 여부는 동물행동실험을 통하여 평가하고 있으며, 사용 되는 자극으로 기계적 자극, 냉 자극, 열 자극, 전기자극 등 다양하다(Ahlgren et al., 1996; Decosterd and Woolf, 2000). 손상된 신경은 재생을 위하여 NF-200, Cdc2, NGF, GNDF, $\mathrm{Nrg}-1, \mathrm{VEGF}$, IGF-1 등 다양한 인자들은 분비하며(Lee et al., 2016), 그 중 neurotrophic factor로 알려진 nerve growth factor (NGF)는 축삭을 보호하며 축삭의 성장을 촉진함과 동시에 슈반세포(schwann cell)의 이주를 도와 myelination 을 촉진시켜 손상된 신경 재생에 관여한다고 알려져 있 다(Hammarberg et al., 1996; Herzberg et al., 1997; Fine et al., 2002). 세포분열 단계 중 성장 2 단계 체세포분열 단계로 의 전이과정에서 가장 핵심적인 역할을 하는 단백질 인
산화 효소인 Cyclin-dependent kinase 2 (Cdc2)는 cyclin B 계 열의 조절 단백질 결합에 의하여 활성화하는 것으로 알 려져 있다(Youn et al., 2002). 손상된 좌골신경에서 $\mathrm{Cdc} 2$ 가 활성화되고 이는 손상 부위의 슈반세포에서 유도되는 것으로 밝혀졌으며 $\mathrm{Cdc} 2$ 가 슈반세포의 증식 및 이주를 활성화하여 축삭 재생에 도움을 주는 것으로 보고되었다 (Wu et al., 2016).

연교(Forsythiae Fructus)는 연교(Forsythia suspensa Vahl) 혹은 의성개나리(Forsythia viridissima Lindley)라고 불리 는 물푸레나무과의 식물이다(Lee and Keum, 1988). 전통적 으로 항염증작용, 해독작용이 있다고 알려져 있으며 다 양한 형태의 감염성 환자에게 치료제로 사용되어져 왔다 (Zhuang et al., 2018). 지난 수년간 연구들에 의하면 연교에 는 항염증, 항산화, 항바이러스, 항암, 간기능 보호, 신경 세포 보호, 그리고 심혈관계 보호작용이 있음이 밝혀졌다 (Nishibe et al., 1982; Bao et al., 2016; Bao et al., 2017; Dong et al., 2017; Zhang et al., 2018). 전 연구에서 연교의 구성성 분인 rengyolone는 간염동물모델에서 항염증효과가 있었 으며 염증성사이토카인의 발현과 iNOS 생성을 저하시켰 다(Lee et al., 2019). 최근 당뇨병성 신경병증 뿐만 아니라 말초성 신경병증에서도 통증 과민화를 유발하는 ROS의 통제가 중요하다는 연구들이 있으며 ROS 조절은 통증경 감효과가 직접적인 관계가 있다고 한다(Fidanboylu et al., 2011; Bachewal et al., 2018). 본 연구에서는 연교를 과거에 서부터 심각한 암환자에게 통증 완화제 용도로 사용되어 왔다는 기록은 있지만 그에 대한 연구는 진행된 바가 없 는 바 이를 규명하고자 실험을 실행하였으며 소기의 성 과가 있어 본 연구에 대하여 보고하고자 한다(Zhuang et al., 2018).

\section{대상과 방법}

\section{실험동물 및 시료}

6주령 수컷 Sprague-Dawley rat (250 300 g) (n=24)를 대 상으로 하여 $22 \pm 3^{\circ} \mathrm{C}$ 을 유지한 환경에서 밤/낮 주기를 맞 추고 물과 사료를 충분히 공급하였으며 1 주일 간 적응기 간을 두었다. 모든 동물실험은 International Association for the Study of Pain의 지침을 지키며 시행되었다(Treede, 2018). 행동 평가 전 통증자극에 대해 예민한 반응을 보이는 개 체는 연구에서 제외하였다. 본 연구는 동의대학교 동물심 의위원회의 규정에 따라 실행하였다. 본 연구에 사용된 rengyolone은 AK Scientific, Inc (San Francisco, MO, USA)에 
서 구입하였으며, 총 RNA 추출제인 TRIzol ${ }^{\circledR}$ 은 Invitrogen (Carlsbad, USA)에서 ONE-STEP RT-PCR Premix kit는 Intron (Korea)에서 구입하였다.

\section{좌골 신경병성 통증의 유발}

Pentobarbital sodium $55 \mathrm{mg} / \mathrm{kg}$ 을 복강 내 주입하고 분비 물 억제를 위하여 atropine $0.2 \mathrm{~mL}$ 을 근육주사마취 후 대 퇴부 쪽 털을 제거하고 베타딘액으로 소독하였다. 좌측 대퇴골 피부를 절개하여 약 $2.0 \mathrm{~cm}$ 길이 정도로 좌골신경 을 노출시키고 4.0 chromic catgut로 $1 \mathrm{~mm}$ 간격으로 4곳 에 매듭을 미끄러지지 않을 정도의 세기로 약하게 결찰 (ligation)하였다(Youn et al., 2002). 이 후 지혈하고 조직과 근육을 층별로 정리하여 3 0 실크로 봉합하고 피부 소독 을 한 후 마취에서 회복시켰다.

\section{통증 측정 방법}

신경병증 통증에 대한 행동검사는 수술 2시간 전, 수술 후 $1,7,14,21$ 일에 걸쳐 실시하였다. 자발적 통증은 아크 릴판 위에 동물을 5 분 간 적응시킨 후 다음 5 분간 뒷발 을 올리는 횟수를 측정하였으며, 외부자극에 대한 철회 반응(withdrawal response)을 보기 위해 von Frey filament test (11.4 mN bending force)를 실시하였다(Bonin et al., 2014), 실제 실험에서는 von Frey filament를 수초 간격으로 양측 발바닥에 10 회 자극하여 발의 철회반응의 횟수를 얻어 백분율로 표시하였다.

반응도(response rate) $(\%)=$ numbers of foot withdrawal/ numbers of the trials $($ ten $) \times 100$

온도자극에 대한 통증을 검사하기 위한 방법은 acetone spray test를 이용하였으며, 양측 뒷다리에 5 분 간격으로 5 회씩 주사기를 이용 acetone을 통각 유발 부위에 가하여 철회반응 횟수를 센 다음 백분율을 구하였다(Vissers and Meert, 2005).

반응도(response rate) $(\%)=$ numbers of foot withdrawal/ numbers of trials (five) $\times 100$

\section{약물 투여 및 샘플 수집}

수술 6일 후부터 rengyolone $100 \mu \mathrm{g} / \mathrm{kg}$ 을 하루 한 번 복 강 내로 주사하는 군(RN군)과 동량 생리식염수를 주사하 는 군(saline군), 그리고 좌골신경을 노출시킨 후 결찰하지
않고 피부를 봉합한 위수술군(sham군)으로 나누어 실험을 진행하였다. 수술 후 21 일 후 마취한 동물을 희생하였으 며 수술 부위의 신경조직을 수집하였으며 액화질소에서 급속 냉동 후 $70^{\circ} \mathrm{C}$ 초저온 냉장고에 보관하였다.

\section{조직에서 NGF와 Cdc2의 측정}

총 RNA를 얻기 위해 $\mathrm{TRIzol}^{\circledR}$ 시약 $1 \mathrm{~mL}$ 을 채취한 쥐 의 신경조직에 넣고 균질화기(homogenizer)을 이용해 잘 게 부순 다음 실온에 5 분 간 방치한 후 chloroform $100 \mu \mathrm{L}$ 를 첨가하여 약 10 20초 간 혼합하고 얼음에서 15 분 간 반응시킨 다음 $4^{\circ} \mathrm{C}, 12,000 \mathrm{rpm}$ 에서 약 15 분 간 원심 분리 하였다. 분리된 total RNA를 정량한 후, primer, DERC water 그리고 ONE-STEP RT-PCR Premix kit를 넣고 Masercycler gradient (Eppendorf, Hamburg, Germany)를 이용하여 증폭 하였다. 각 $\mathrm{PCR}$ 산물들의 양적 비교를 위하여 $1 \mathrm{X} \mathrm{TAE}$ buffer로 $1 \%$ agarose gel을 만들고 well 당 각각의 primer 를 넣고 DNA gel loading solution을 섞어서 loading 한 후 $100 \mathrm{~V}$ 에서 전기 영동을 실시하였다. DNA 분리가 끝난 후 gel을 ethidium bromide (EtBr, Sigma)로 염색한 후 UV 하 에서 확인하였다. 본 실험에 사용한 rat NGF의 염기 서열 은 sense CCC-CGA-ATC-CTG-TAG-AGA, antisense CACGCA-GGC-TGT-ATC-TAT이었으며, $\mathrm{Cdc} 2$ 의 염기 서열은 sense GGG-GAT-TCA-GAA-ATT-GAT-CA, antisense TGTCAG-AAA-GCT-ACA-TCT-TC이였으며, $\beta$-actin은 sense ATG-GTG-GGT-ATG-GGT-CAG-AA, antisense TCC-ATATCGTCC-CAG-TTG-GT였다.

\section{통계}

전 후에 대한 비교는 Wilcoxon signed rank test를 이용하 여 다른 군 사이에서의 비교는 Mann-Whitney test를 사용 하였다. 다중비교일 경우 Kruskal-Wallis test를 사용하고 사후분석으로 Bonferroni's method를 이용하였다. 분석에 사용된 평균값은 평균값 \pm 표준오차로 표시하였고, 유의 수준 $(P)$ 은 0.05 으로 설정하였다.

\section{결 과}

\section{일반적인 행동 양상}

모든 대상 동물은 신경 손상 후 정상적인 체중증가를 보였으며, 수술 처치한 뒷다리는 경도 eversion 현상을 보 였다. 수술 직 후 신경 손상 동물들은 기계적 자극과 온 도자극에 대하여 과민성을 보였으며 본 실험에서는 $50 \%$ 
이상의 과민반응도를 보여준 22마리의 동물만 연속적인 실험대상이 되었다.

\section{신경병증성 통증의 발생}

모든 동물은 수술 전 von Frey filament 혹은 아세톤에 대하여 거의 반응을 보이지 않았으나 수술 후 7일 후부 터 수술 처치하지 않은 오른쪽 다리에 비하여 말초신경 이 손상된 왼쪽에서 이질통이 증가하였음을 알 수 있었 다(Fig. 1). 7일 후부터는 양쪽 다리반응을 비교하면 통계 적으로 유의한 차이가 있음을 알 수 있다 $(P<0.01)$.

\section{기계적인 이질통에 대한 약물 투여 후 반응}

$11.0 \mathrm{mN}$ bending force에서 반복되는 기계적 자극에 대한 발의 회피 빈도를 시간에 따라 표시하였다(Fig. 2). Sham 군은 기계적인 자극에 거의 반응이 없었으며 $\mathrm{RN}$ 군에서 von Frey filament에 대한 수술 후 7일 차에 평균 반응도 는 $62.58 \%$ 였으나 수술 후 21 일 차에 평균 $41.92 \%$ 로 통계 적으로 유의미한 변화를 보였다 $(P<0.01)$. 반면 위양성군 인 saline군에서는 같은 시기에 유의미한 변화가 없었다 $(P=0.42)$. Saline군과 $\mathrm{RN}$ 군의 반응도의 차이는 7일 차부터

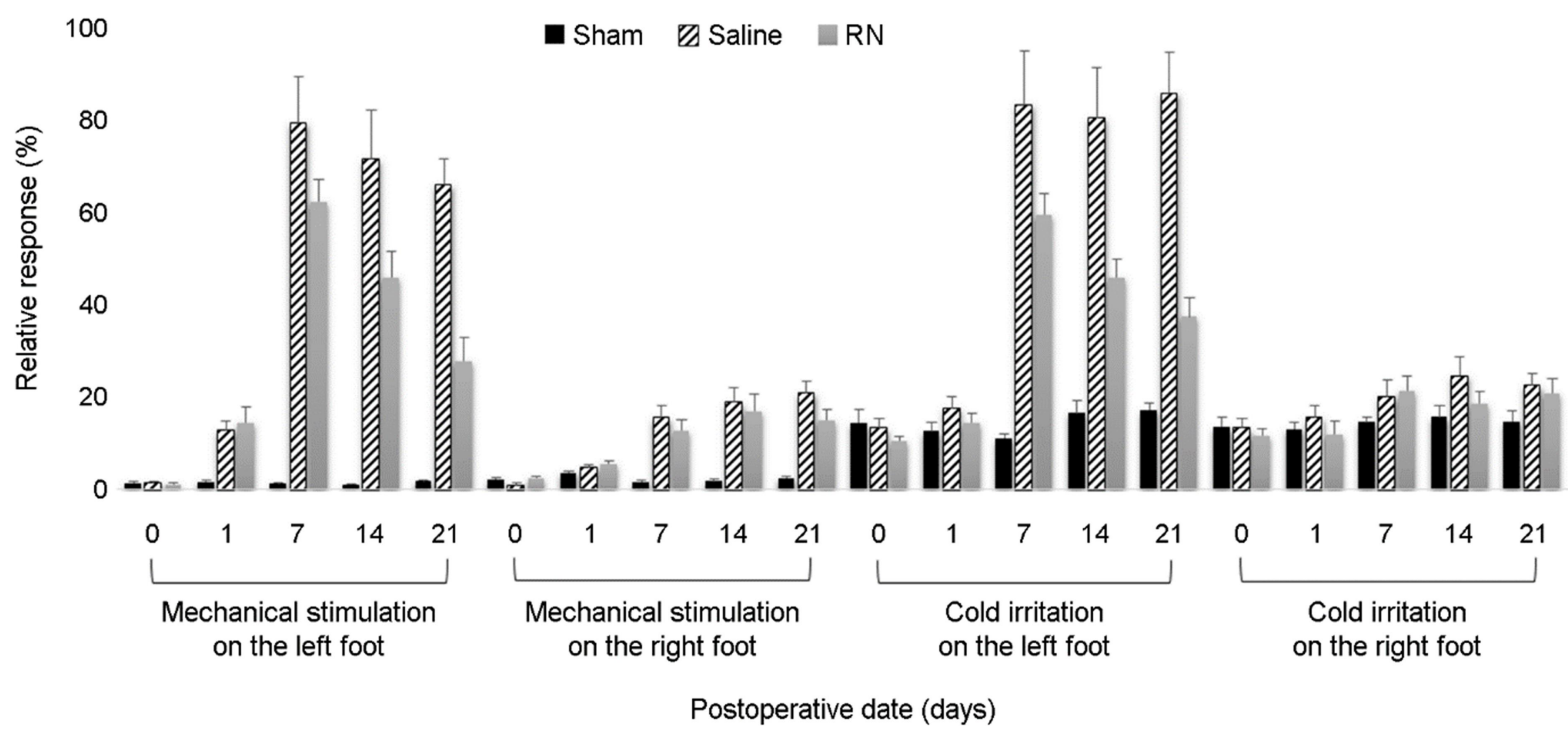

Fig. 1. Responsiveness of mechanical and thermal stimuli to both feet. Both feet were stimulated to verify the induction of neuralgia. It was found that the sensitivity to pain stimulation was significantly increased in the left foot that caused neuropathy on the 7th day after surgery.

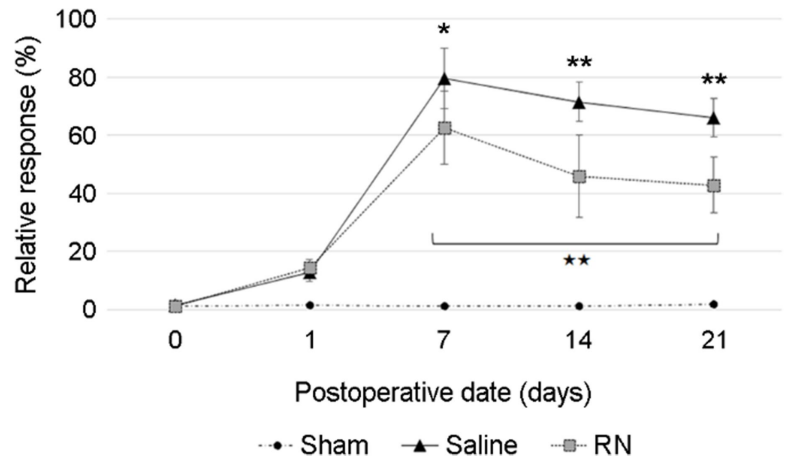

Fig. 2. Behavioral response to mechanical stimuli in neuropathic pain model. A Response to von Frey filament is used as an index of mechanical allodynia. Mean \pm SEM. is the response in sham group, in saline group, and in $\mathrm{RN}$ group. Significant difference compared with saline operated group $(* ; P<0.05, * * ; P<0.01)$.

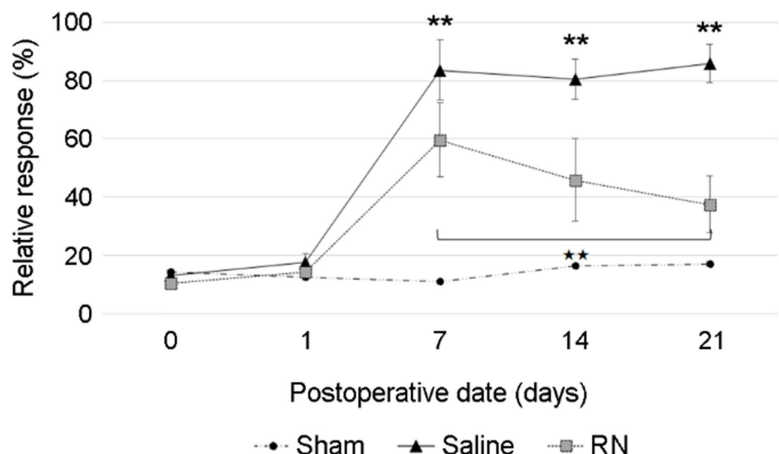

Fig. 3. Behavioral response to thermal stimuli in neuropathic pain model. A Response to Acetone evaporative cooling is used as an index of thermal allodynia. Mean \pm SEM. is the response in sham group $(\mathrm{n}=7)$, in saline group $(\mathrm{n}=8)$, and $\mathrm{RN}$ group $(\mathrm{n}=7)$. Significant difference compared with saline operated group $(* * ; P<0.01)$. 


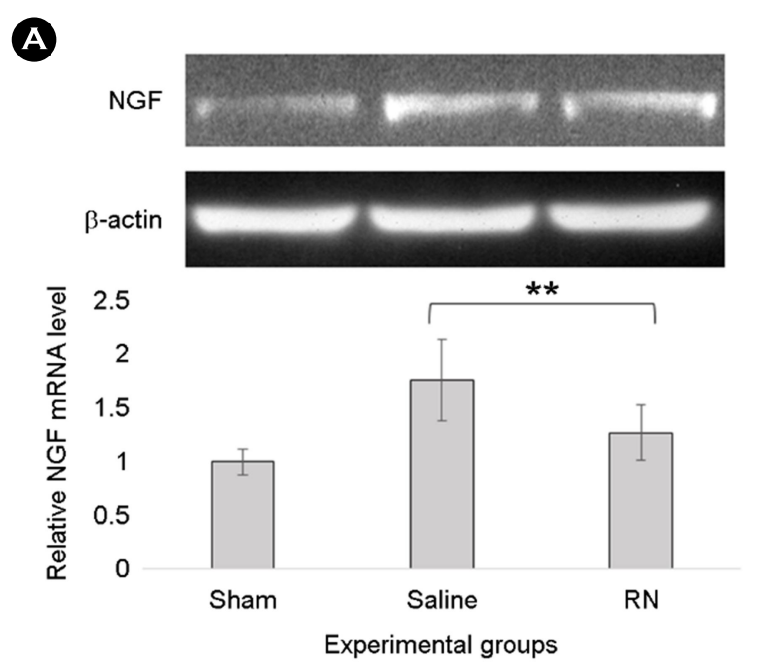

B

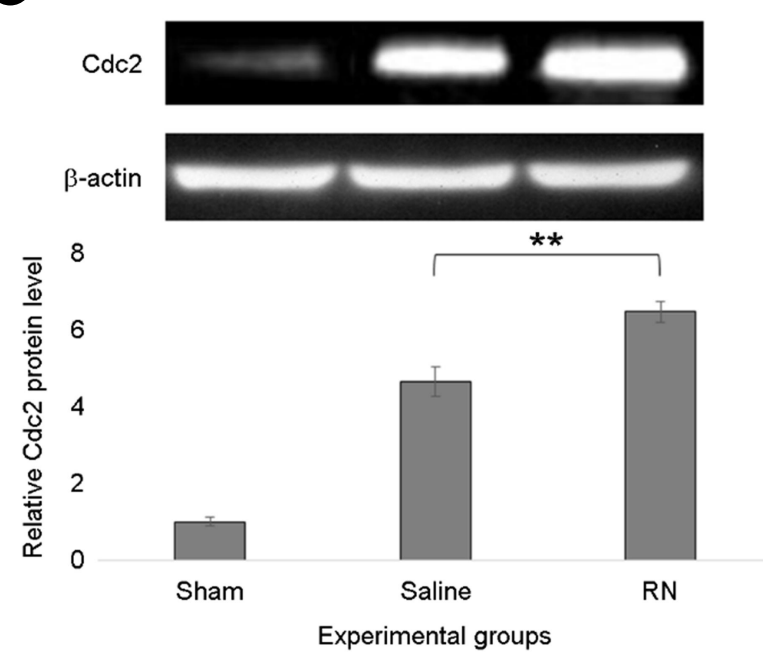

Fig. 4. The mRNA expression of NGF and Cdc2 in sciatic nerve. (A) The mRNA expression of NGF (B) The mRNA expression of Cdc2 After an animal sacrifice, samples were collected from the damaged sciatic nerve and analyzed. $* *$ significant difference compared with saline operated group $(P<0.01)$.

발생하기 시작 $(P=0.02)$ 하였으며 21일경에 그 차이 더욱 커졌다 $(P<0.01)$. 신경통증이 유발된 실험동물에서 rengyolone는 기계적인 이질통에 대하여 통증 억제작용을 가지 고 있다고 사료된다.

\section{온도자극으로 유발된 이질통에 대한 약물 투여 후 반응}

아세톤이 증발되면서 발생하는 저온 감각에 대한 이질 통이 발생한 실험동물에서 약물 투여에 따른 반응(Fig. 3) 을 보면 Rengyolone 투여 전 아세톤에 대한 반응은 수술 후 7일 차에 평균 반응도는 $59.62 \%$ 였으나 수술 후 21 일
차에는 평균 $37.51 \%$ 로 유의미한 하강을 보였다 $(P<0.01)$. 역시 saline군에서는 같은 시기에 유의미한 변화가 없었다 $(P=0.35)$. Saline군과 $\mathrm{RN}$ 군의 반응도의 차이는 7 일 차부 터 발생하기 시작 $(P<0.01)$ 하였으며 21일경에 그 차이 더 욱 커졌다 $(P<0.01)$. 이러한 결과는 신경통증동물모델에서 Rengyolone은 온도자극으로 유발된 이질통에 대한 억제 작용 가진다는 사실을 알 수 있었다.

\section{$\mathrm{NGF}$ 와 $\mathrm{Cdc} 2$ 의 측정 결과}

$\mathrm{RN}$ 군에서 신경 손상을 유발한 좌골신경을 수집하고 다른 군에서 동일한 부위를 채취하여 $\mathrm{mRNA}$ 를 측정하였 다(Fig. 4. A, B). Sham군의 mRNA 발현을 기준으로 다른 군의 단백발현을 상대적인 비율로 표현하였다. RN군에서 는 NGF mRNA 발현은 Saline군에 비하여 $28.1 \%$ 더 적게 발현되었음을 알 수 있었으며 통계적으로 유의한 차이를 보였다 $(P<0.01)$. Cdc2 mRNA 발현은 Saline군과 비교하여 $\mathrm{RN}$ 군에서 $39.2 \%$ 상승하였으며 통계적으로 유의한 차이 를 보였다 $(P<0.01)$.

\section{고 찰}

신경병성 통증 연구에는 여러 동물모델을 이용할 수 있으며, 그 중 가장 흔하게 사용되는 모델은 chronic injury model (chronic constriction injury, $\mathrm{CCl}$ ) 모델, 좌골신경 결 찰모델, 그리고 척수후근 결찰모델 등이 있다(Bennett and Medicine, 1993). 이 중 CCI 모델은 신경을 느슨히 협착하 여 신경 내 부종이 발생함으로 통증을 유발하는 모델이 다. 신경을 절단하는 동물모델인 경우 비정상적인 신경 흥분이 신경병성 통증을 유발하는 등 다소 상이한 결과 를 보일 수 있어 본 연구에서는 $\mathrm{CCI}$ 모델을 이용하였다.

신경병증성 통증은 일반적인 통증 전달과정과는 다른 신경 해부학적인 특징을 가지고 있기 때문에 일반적으로 통증 완화제로 사용되는 비스테로이드계 항염증제나 아 편계 약물을 포함한 일반 진통제에 잘 반응하지 않는다 고 알려져 있다(Finnerup et al., 2005; Attal et al., 2006). 이런 비정상적인 통증감각기성 반응들인 신경병증성 통증이 발생된 동물에서는 손상된 말초신경과 연관된 척수에서 신경적응적(neuroplastic) 변화들을 관찰할 수 있다(Baron, 2006). 말초신경의 손상으로 유발된 신경적응학적 변화로 신경세포의 퇴행성 변화와 함께 신경 손상 원위부에서 신경섬유의 변성을 유발하고 표적장기의 위축을 유발하 는데, 특히 골격근은 탈신경지배성 위축이 발생하며 근육 
량과 근력의 감소, 근섬유 직경의 감소가 유발되며, 근섬 유형의 변환, 섬유성 및 지방결합 조직량의 증가 등이 유 발된다(Baron, 2006; Yao and Sessle, 2018). 따라서, 좌골신 경 손상의 치료효과 분석을 위해 약물을 투여한 후 중재 기간 동안 행동학적 관찰, 육안적 평가, 면역조직학적 평 가를 진행한다(Decosterd and Woolf, 2000). 이 중 행동학적 관찰 항목으로는 동물의 족적을 이용하여 기능적 회복을 관찰할 수 있는 좌골신경 기능지수인 $\mathrm{SFI}$, 열 자극에 대 한 통증 역치를 측정하기 위한 plastar test, 기계적 자극에 의한 통증 역치를 측정하는 touch test, 그리고 냉 자극에 대한 통증 역치를 측정하는 냉수조 방법과 아세톤증발법 등이 있다(Kupers et al., 1992). 본 연구에서는 기계적 자극 과 냉 자극을 이용하여 통증에 대한 역치를 판정하는 기 존의 방법을 수정한 Lee (Lee et al., 2000)의 방법을 이용하 였다. 이 방법의 장점은 빈도수가 반응도(\%)로 결과를 환 산하여 측정하여 보다 정량적인 측정지수를 사용한다는 점이다. 육안적 평가 항목들로는 Muscle wet weight, 축삭 의 길이 및 직경 등이 포함되는데 본 연구에서는 약물투 입기간과 회복기간을 고려하여 본 연구의 결과에는 포함 하지 않았다.

Rengyolone의 투입은 동물의 말초신경 손상 후에 발생 된 기계자극 혹은 냉각 이질통에서 유의한 진통효과 보 였다. 동물모델에서 말초신경 통증 유발확립을 확인하기 위하여 양쪽 발에 자극을 동물행동평가에서 시행하였으 며 신경손상을 일으킨 좌측에 비하여 우측 발에서 현저 하게 높은 자극 역치를 보임을 알 수 있었다. 특이한 점 은 7일 이후 손상되지 않는 우측 발에서 기계적 자극 및 냉 자극에 대한 민감도가 높아져 가는 경향을 볼 수 있 는데 이는 말초신경의 손상에 의한 교감신경의 활성화와 손상된 말초신경과 연결된 중추신경의 신경학적 변화와 관련이 있다는 과거 연구 결과와 연관이 있다고 사료된 다(Treede, 2018; Lee et al., 2019). 본 연구에서 기계적 자 극에 대한 반응도는 RN군과 saline군 모두 7일 이후에 통 증반응도가 최대치였으며 이 후 하강하는 경향을 보였다. 7일, 14일, 21일 모두 두 군 사이에는 통계적으로 유의한 차이를 보였으며 이는 약물 투입이 말초신경병증에 의한 통증을 완화시킨다고 볼 수 있는 결과이다. 아세톤 유발 냉각 이질통에서도 기계자극 통증과 유사한 경향이 나타 났으며, 기계자극 통증과 다른 점은 saline군에서 7일이 아닌 21일에 최대반응도가 나타난 점이다.

신경손상은 BDNF, neurotropim-3, neurotropin-4/5, NGF 등 여러 신경영양인자를 발현도 변화시킨다(Fine et al., 2002).
이들 인자들은 신경의 재생과 생성에 역할을 하는 것으 로 알려져 있으며 동시에 통증의 유발과 깊은 관계가 있 다(Low et al., 1997; Fine et al., 2002). NGF는 좌골신경의 절 단이나 압박손상 시 p75 neutrophin receptor와 더불어 손상 부위의 원위부 분절에서 발현이 빠르게 증가한다(Low et al., 1997). 과거 연구 중 손상된 신경에 anti-NGF를 투여 하면 손상 초기에는 항통증효과를 보이는 반면 손상되지 않은 신경에 NGF를 투여하면 이질통이 나타난다(Ramer and Bisby, 1999). 이 NGF는 신경의 재생에 있는 중대한 역할을 하지만 신경병증 통증 발생에서 $\mathrm{NGF}$ 가 어떤 역 할을 담당하며 $\mathrm{NGF}$ 를 차단하는 것이 오히려 신경병증 통 증 치료에 도움을 줄 가능성이 있다는 주장도 있다(Hefti et al., 2006). 또한 NGF의 관련된 통증발현은 면역계도 관 여한다. 통증을 지각하는 말초의 유해수용기(nociceptor) 에는 면역수용기가 다수 존재하는데, IL- $1 \beta, \mathrm{IL}-6, \mathrm{TNF} \alpha$, bradykinin, prostanoids 등이 통증 발생에 상당한 역할을 수행한다고 알려져 있다(Woolf et al., 1997; Sommer and Schäfers, 2004). 손상된 신경은 염증반응을 유발하고 cytokine의 발현이 증가되며, 전염증성사이토카인의 증가는 $\mathrm{NGF}$ 의 발현을 증가시키며 NGF는 유해수용기를 민감화 하여 통증을 발생시킬 수 있다(Sommer and Schäfers, 2004; Okuse and biology, 2007). 이러한 전염증성사이토카인에 대하여 저해효과가 있는 물질이 통증 완화에 효능이 있 다는 다수 연구 결과도 발표되었다(Okamoto et al., 2001; Milligan et al., 2005; Schäfers and Sommer, 2007). 본 연구에 서 사용된 rengyolone은 과거 연구 결과 항염증 및 전염 증성사이토카인 발현을 낮추는 효능이 있으며 전염증성 사이토카인 저해제와 같은 기전으로 통증 완화에 도움이 될 것이라 예상되었다(Kim et al., 2006; Lee et al., 2019). 좌 골신경 손상 후 슈반세포의 증식 유도 단백질인 $\mathrm{Cdc} 2$ 는 최근 연구에 의하면 손상된 좌골신경에서 시간 의존적으 로 $\mathrm{Cdc} 2$ 가 활성화되고 이는 손상 부위의 슈반세포에서 유도되는 것으로 다시 $\mathrm{Cdc} 2$ 가 슈반세포의 증식 및 세포 이주 활성화를 증가시켜 축삭 재생에 중요한 역할을 한 다고 한다(Stagg et al., 2011). 본 연구에 의하면 saline군과 $\mathrm{RN}$ 군에서 $\mathrm{NGF}$ 와 $\mathrm{Cdc} 2$ 발현의 유의한 차이가 발생하였 다. Sham군에서에 $\mathrm{NGF}$ 와 $\mathrm{Cdc} 2$ 발현과 다른 군들의 발현 은 유의한 차이를 보이면 증대하였으며 이는 신경세포의 증식과 재생이 이루어지고 있다고 사료된다. 하지만 NGF 와 $\mathrm{Cdc} 2$ 발현은 서로 다른 경향을 보인다. $\mathrm{NGF}$ 는 $\mathrm{RN}$ 군 에서 발현이 saline군에서 비해 저하되었으며, $\mathrm{Cdc} 2$ 발현 은 그 반대로 상승한 결과를 보였다. 먼저 $\mathrm{Cdc} 2$ 의 발현 
증대는 신경 재생을 위한 슈반세포의 증식과 세포 이주 활성화로 인하여 두 군 모두 증대한 것으로 보이며 한달 도 안된 짧은 기간에 아직 신경 재생이 진행되고 있다 는 증거라고 생각된다. 두 군에서 $\mathrm{Cdc} 2$ 발현 차이가 있 지만 사용물질이 신경 재생에 어떠한 방식으로 간섭하 고 있는지는 아직 의문인 상태이다. NGF의 발현 양상은 rengyolone의 투여로 전염증성물질에 영향을 주어 발현이 저지되었다고 예상되며 이런 염증성물질 차단은 과거 연 구에서 확인할 수 있다. 염증성물질의 차단은 전염증성사 이토카인의 상승을 저지시키며 이에 NGF의 발현에도 영 향을 주고 있다고 사료된다.

이번 연구의 목적은 신병병성 통증을 유발한 동물모델 에서 통증의 종류에 따라 연교의 생리활성물질 중 하나 인 rengyolone의 효과를 행동학적 평가와 mRNA 분석을 통해 알아보고자 하였다. 실험 결과를 정리하면 다음과 같다. 1) 신경병성 통증 발생 시 rengyolone 투여는 신경통 증을 경감시킨다. 2) 신경병성 통증의 경감은 신경 재생에 서 통증 유발과 관련있는 $\mathrm{NGF}$ 의 발현 저지와 관련이 있 다고 예상된다. 현재 연교에 대한 여러 가지 연구가 진행 되고 있지만 항통증에 대한 연구는 진행된 바가 없으며 이에 대한 기초 연구는 차후 연교와 관련된 항통증제 개 발의 기초가 될 것이라 예상된다.

\section{ACKNOWLEDGEMENT}

None.

\section{CONFLICT OF INTEREST}

The researcher claims no conflicts of interest.

\section{REFERENCES}

Ahlgren SC, Wang JF, Levine JD. C-fiber mechanical stimulusresponse functions are different in inflammatory versus neuropathic hyperalgesia in the rat. Neuroscience. 1996. 76: 285-290. Attal N, Cruccu G, Haanpää M, Hansson P, Jensen TS, Nurmikko T, Sampaio C, Sindrup S, Wiffen P. EFNS guidelines on pharmacological treatment of neuropathic pain. European Journal of Neurology. 2006. 13: 1153-1169.

Bachewal P, Gundu C, Yerra VG, Kalvala AK, Areti A, Kumar A. Morin exerts neuroprotection via attenuation of ros induced oxidative damage and neuroinflammation in experimental diabetic neuropathy. Biofactors. 2018. 44: 109-122.

Bao J, Ding RB, Liang Y, Liu F, Wang K, Jia X, Zhang C, Chen M,
Li P, Su H. Differences in chemical component and anticancer activity of green and ripe forsythiae fructus. The American Journal of Chinese Medicine. 2017. 45: 1513-1536.

Bao J, Liu F, Zhang C, Wang K, Jia X, Wang X, Chen M, Li P, Su $\mathrm{H}$, Wang Y. Anti-melanoma activity of forsythiae fructus aqueous extract in mice involves regulation of glycerophospholipid metabolisms by uplc/q-tof ms-based metabolomics study. Scientific Reports. 2016. 6: 39415.

Baron R. Mechanisms of disease: Neuropathic pain - a clinica perspective. Nature Clinical Practice Neurology. 2006. 2: 95 $-106$.

Bennett GJ, Xie YK. A peripheral mononeuropathy in rat that produces disorders of pain sensation like those seen in man. Pain. 1988. 33: 87-107.

Bennett GJ. An animal model of neuropathic pain: A review. Muscle \& Nerve: Official Journal of the American Association of Electrodiagnostic Medicine. 1993. 16: 1040-1048.

Bonin RP, Bories C, De Koninck Y. A simplified up-down method (sudo) for measuring mechanical nociception in rodents using von frey filaments. Molecular Pain. 2014. 10: 1744-8069.

Decosterd I, Woolf CJ. Spared nerve injury: An animal model of persistent peripheral neuropathic pain. Pain. 2000. 87: 149-158.

Djouhri L, Koutsikou S, Fang X, McMullan S, Lawson SN. Spontaneous pain, both neuropathic and inflammatory, is related to frequency of spontaneous firing in intact c-fiber nociceptors. Journal of Neuroscience. 2006. 26: 1281-1292.

Dong Z, Lu X, Tong X, Dong Y, Tang L, Liu M. Forsythiae fructus: A review on its phytochemistry, quality control, pharmacology and pharmacokinetics. Molecules. 2017. 22: 1466.

Fidanboylu M, Griffiths LA, Flatters SJL. Global inhibition of reactive oxygen species (ros) inhibits paclitaxel-induced painful peripheral neuropathy. PloS One. 2011. 6: e25212.

Fine EG, Decosterd I, Papaloïzos M, Zurn AD, Aebischer P. GDNF and NGF released by synthetic guidance channels support sciatic nerve regeneration across a long gap. European Journal of Neuroscience. 2002. 15: 589-601.

Finnerup NB, Otto M, McQuay HJ, Jensen TS, Sindrup SH. Algorithm for neuropathic pain treatment: An evidence based proposal. Pain. 2005. 118: 289-305.

Hammarberg H, Piehl F, Cullheim S, Fjell J, Hökfelt T, Fried K. GDNF mRNA in schwann cells and DRG satellite cells after chronic sciatic nerve injury. Neuroreport. 1996. 7: 857-860.

Hefti FF, Rosenthal A, Walicke PA, Wyatt S, Vergara G, Shelton DL, Davies AM. Novel class of pain drugs based on antagonism 
of NGF. Trends in Pharmacological Sciences. 2006. 27: 85-91. Herzberg U, Eliav E, Dorsey JM, Gracely RH, Kopin IJ. NGF involvement in pain induced by chronic constriction injury of the rat sciatic nerve. Neuroreport. 1997. 8: 1613-1618.

Hofmann HA, De Vry J, Siegling A, Spreyer P, Denzer D. Pharmacological sensitivity and gene expression analysis of the tibial nerve injury model of neuropathic pain. European Journal of Pharmacology. 2003. 470: 17-25.

Kim JH, Kim DH, Baek SH, Lee HJ, Kim MR, Kwon HJ, Lee CH. Rengyolone inhibits inducible nitric oxide synthase expression and nitric oxide production by down-regulation of NF- $\mathrm{BB}$ and p38 map kinase activity in lps-stimulated raw 264.7 cells. Biochemical Pharmacology. 2006. 71: 1198-1205.

Kupers RC, Nuytten D, De Castro-Costa M, Gybels JM. A time course analysis of the changes in spontaneous and evoked behaviour in a rat model of neuropathic pain. Pain. 1992. 50: 101-111.

Lee BH, Won R, Baik EJ, Lee SH, Moon CH. An animal model of neuropathic pain employing injury to the sciatic nerve branches. Neuroreport. 2000. 11: 657-661.

Lee CH, Lee JE, Choi YJ, Lee EJ, Oh MS. Effects of the herbal medicine in animal models for treatment of sciatic nerve impairment: A review of animal study reports. Journal of Korean Medicine Rehabilitation. 2016. 26: 9-21.

Lee EB, Keum HJ. Pharmacological studies on forsythiae fructus. Korean Journal of Pharmacognosy. 1988. 19: 262-269.

Lee GH, Hyun KY, Kang YJ. Anti-inflammatory modulating effect of rengyolone in rat. Biomedical Science Letters. 2019. 25: 54-59.

Low PA, Nickander KK, Tritschler HJ. The roles of oxidative stress and antioxidant treatment in experimental diabetic neuropathy. Diabetes. 1997. 46: S38-S42.

Milligan ED, Sloane EM, Langer SJ, Cruz PE, Chacur M, Spataro L, Wieseler-Frank J, Hammack SE, Maier SF, Flotte TR. Controlling neuropathic pain by adeno-associated virus driven production of the anti-inflammatory cytokine, interleukin-10. Molecular Pain. 2005. 1: 1744-8069.

Nishibe S, Okabe K, Tsukamoto H, Sakushima A, Hisada S, Baba H, Akisada T. Studies on the chinese crude drug" forsythiae fructus." Vi. The structure and antibacterial activity of suspensaside isolated from forsythia suspensa. Chemical and Pharmaceutical Bulletin. 1982. 30: 4548-4553.

Okamoto K, Martin DP, Schmelzer JD, Mitsui Y, Low PA. Proand anti-inflammatory cytokine gene expression in rat sciatic nerve chronic constriction injury model of neuropathic pain.
Experimental Neurology. 2001. 169: 386-391.

Okuse K. Pain signalling pathways: From cytokines to ion channels. The International Journal of Biochemistry \& Cell Biology. 2007. 39: 490-496.

Raghavendra V, Tanga F, DeLeo JA. Inhibition of microglial activation attenuates the development but not existing hypersensitivity in a rat model of neuropathy. Journal of Pharmacology and Experimental Therapeutics. 2003. 306: 624-630.

Ramer MS, Bisby MA. Adrenergic innervation of rat sensory ganglia following proximal or distal painful sciatic neuropathy: Distinct mechanisms revealed by anti-NGF treatment. European Journal of Neuroscience. 1999. 11: 837-846.

Schäfers M, Sommer C. Anticytokine therapy in neuropathic pain management. Expert Review of Neurotherapeutics. 2007. 7: 1613-1627.

Sommer C, Schäfers M. Mechanisms of neuropathic pain: The role of cytokines. Drug Discovery Today: Disease Mechanisms. 2004. 1: 441-448.

Stagg NJ, Mata HP, Ibrahim MM, Henriksen EJ, Porreca F, Vanderah TW, Malan TP. Regular exercise reverses sensory hypersensitivity in a rat neuropathic pain modelrole of endogenous opioids. Anesthesiology: The Journal of the American Society of Anesthesiologists. 2011. 114: 940-948.

Staud R, Bovee CE, Robinson ME, Price DD. Cutaneous c-fiber pain abnormalities of fibromyalgia patients are specifically related to temporal summation. Pain. 2008. 139: 315-323.

Staud R, Craggs JG, Robinson ME, Perlstein WM, Price DD. Brain activity related to temporal summation of c-fiber evoked pain. Pain. 2007. 129: 130-142.

Treede RD. The international association for the study of pain definition of pain: As valid in 2018 as in 1979, but in need of regularly updated footnotes. Pain Report. 2018. 3.

Vissers K, Meert T. A behavioral and pharmacological validation of the acetone spray test in gerbils with a chronic constriction injury. Anesth Analg. Anesthesia \& Analgesia. 2005. 101: 457 -464 .

Woolf C, Allchorne A, Safieh Garabedian B, Poole S. Cytokines, nerve growth factor and inflammatory hyperalgesia: The contribution of tumour necrosis factor $\alpha$. British Journal of Pharmacology. 1997. 121: 417-424.

Wu J, Zhao Z, Zhu X, Renn CL, Dorsey SG, Faden A. Cell cycle inhibition limits development and maintenance of neuropathic pain following spinal cord injury. Pain. 2016. 157: 488.

Yao D, Sessle BJ. Face sensorimotor cortex undergoes neuroplastic changes in a rat model of trigeminal neuropathic pain. 
Experimental Brain Research. 2018. 236: 1357-1368.

Youn SH, Kim SH, Park HS, Kim EY, Park HC, Park YG. The effect of mk-801 and naloxone in a sympathetically independent neuropathic pain rat model. Journal of Korean Neurosurgical Society. 2002. 32: 246-255.

Zhang Y, Miao H, Yan H, Sheng Y, Ji L. Hepatoprotective effect of forsythiae fructus water extract against carbon tetrachlorideinduced liver fibrosis in mice. Journal of Ethnopharmacology. 2018. 218: 27-34.

Zhuang J, Ma XR, Wang Xue. Thoughts on the treatment of cancer pain under the guidance of traditional chinese medicine. TMR Theory and Hypothesis. 2018. 1: 83-88.

Ziegler D, Hanefeld M, Ruhnau K, Mei H, Lobisch M, Schütte K,
Gries F, Diabetologia ASGJ. Treatment of symptomatic diabetic peripheral neuropathy with the anti-oxidant $\alpha$-lipoic acid. 1995. Diabetologia. 38: 1425-1433.

Ziegler D, reviews. Painful diabetic neuropathy: Treatment and future aspects. 2008. 24: S52-S57.

https://doi.org/10.15616/BSL.2020.26.4.310

Cite this article as: Lee GH, Hyun KY. Ameliorative Potential of Rengyolone Against CCI-induced Neuropathic Pain in Rats. Biomedical Science Letters. 2020. 26: 310318. 